\title{
PENGARUH PAKET PEMBELAJARAN PENDIDIKAN LINGKUNGAN HIDUP DAN GAYA KOGNITIF TERHADAP KEMAMPUAN MEMECAHKAN MASALAH LINGKUNGAN \\ (Studi Eksperimen pada Jurusan Kimia, FMIPA Universitas Negeri Jakarta)
}

\section{AGUNG PURWANTO}

Dosen Jurusan Kimia FMIPA UNJ

\begin{abstract}
The objective of the research was aimed at finding out whether there is effect of the environmental education learning package and cognitive style on environmental problem solving skills. This research conducted was exsperiment methode. The target of population is the students at the Mathematics and Natural Sciences at the State University of Jakarta. Then accessible of population is Department of Chemistry and take it by randomly $(n=40)$. The research came five conclusions are follow: the first, as $a$ whole the ability of students problem-solving learning environment in an integrated package of environmental education is high than the monolithic environmental education learning package; the second, the ability of students problem-solving learning environment in field independent style cognitive is not high than the field dependent style cognitive; the third, interaction effect between learning and cognitive styles environmental education package; the fourth, the ability of students to solve environmental problems based on cognitive style of field dependent on an integrated learning package environmental education lower than on learning environmental education monolithic package, and the five, there is the ability of students to solve environmental problems based on field independent cognitive styles in an integrated learning package environmental education is high than on learning environmental education monolithic package.
\end{abstract}

Keywords : environmental education learning package, cognitive style, and environmental problem solving skills.

\section{PENDAHULUAN}

Peradaban manusia dalam setiap periode waktu yang dilewatinya terus mengalami perubahan dan kemajuan seiring dengan per-kembangan ilmu dan teknologi. Perubahan yang terjadi ini selain memberikan manfaat positif, juga berdampak negatif. Salah satu dampak yang telah terjadi dan masih terus berlanjut pada masa sekarang dalam kehidupan dan peradaban manusia adalah dampak bagi lingkungan yang ada di sekitar manusia itu sendiri. Masalah yang menyangkut lingkungan dari waktu ke waktu dirasakan semakin sulit dan kompleks, sementara kemampuan manusia untuk mengatasi masalah lingkungan tidak meningkat dan berkembang secara signifikan dengan meningkat dan kompleksnya masalah lingkungan itu sendiri.

Kenyataan akan adanya kendala dalam memecahkan masalah lingkungan, tak terkecuali juga terjadi pada

55

Volume XIII

Nomor 01

Maret 2012

ISSN 1411-1829 
mahasiswa di Jurusan Kimia Fakultas Matematika dan Ilmu Pengetahuan Alam (FMIPA), Universitas Negeri Jakarta (UNJ). Keadaan ini diduga antara lain karena pembelajaran pendidikan lingkungan hidup lebih menekankan aspek penguasaan pengetahuan pada ranah ingatan dan pemahaman, bukan pada ranah aplikasi, analisis, sintesis, dan evaluasi. Selain dari pada itu, pemilihan strategi pembelajaran mono-litik selama ini, diduga juga mem-berikan kontribusi munculnya kendala dalam memecahkan masalah lingkungan.

Kemampuan memecahkan masalah merupakan perilaku yang penting bagi keberhasilan pendidikan lingkungan hidup (PLH) yang berkelanjutan (environmental education for sustainability). Pemilihan strategi pembelajaran pendidikan lingkungan hidup dengan cara mengintegrasikan dengan salah satu mata kuliah yang termasuk dalam kurikulum inti di Jurusan Kimia FMIPA UNJ, seperti Kimia Dasar, diduga lebih dapat mewujudkan kompetensi mahasiswa yang mampu memecahkan masalah lingkungan yang cenderung kompleks.

Kualitas lingkungan yang semakin menurun diyakini memicu berbagai masalah dan bencana yang memerlukan keterlibatan manusia di dalam upaya pemecahannya. Didalam upaya memecahkan masalah ling-kungan pada dasarnya merupakan upaya terpadu yang mencakup pengalokasian dan pemanfaatan lingkungan secara optimal bagi umat manusia secara berkelanjutan. Kondisi ideal yang diharapkan dengan pemecahan masalah lingkungan yang baik, diharapkan dapat ditekan semaksimal mungkin timbulnya dampak negatif kemajuan kehidupan manusia ter-hadap lingkungan.
Kenyataan di lapangan seiring perkembangan kehidupan modern tidak selalu dibarengi dengan kesiapan dalam hal kemampuan umat manusia untuk mengantisipasi dampak negatif yang ditimbulkan. Fakta memberikan bukti bahwa kompleksitas perubahan dalam sendi kehidupan yang dipicu oleh perkembangan teknologi yang sangat pesat di bidang industri telah mendorong terjadi perubahan sendi-sendi kehidupan sosial manusia. Dalam kehidupan seharihari dapat ditemukan, bahwa begitu mudah manusia dapat memanfaatkan berbagai produk olahan dari dunia industri baik yang berupa bahan makanan, obat-obatan, maupun berbagai per-alatan yang belum tentu aman digunakan bagi kesehatan.

Di lain pihak tidak dapat dipungkiri, bahwa berbagai perilaku manusia yang bersifat destruktif juga menjadi pemicu kerusakan lingkungan yang kian hari semakin marak, seperti peristiwa: tanah longsor, banjir bandang, pencemaran sungai, pen-cemaran laut, pencemaran udara, pencemaran tanah, intrusi air laut, desertifikasi, pemanasan global, dan sebagainya.

Manusia sebagai makhluk konsumen yang begitu mudah mendapatkan berbagai produk-produk dari industri tersebut dihadapkan kepada dua kemungkinan, yakni: pertama, manusia memanfaatkan produk industri secara efisien. Kedua, manusia memanfaatkan produk industri dengan boros. Pada kemungkinan yang kedua dari pola konsumsi di atas merupakan awal dari permasalahan lingkungan di dalam suatu komunitas manusia yang berkedudukan sebagai suatu masya-rakat.

Sehubungan dengan kemampuan memecahkan masalah lingkungan bagi mahasiswa, maka menjadi konsekuensi

\begin{tabular}{|l|l|l|l|}
\hline Volume XIII & Nomor 01 & Maret 2012 & ISSN 1411-1829 \\
\hline
\end{tabular}


dalam lingkup pendidikan di perguruan tinggi perlu mempersiapkan paket pembelajaran yang dapat memberikan bekal kepada mahasiswa agar dapat mengembangkan kemampuan dalam memecahkan masalah lingkungan.

Di kalangan mahasiswa perlu diperdalam selain pengetahuan tentang lingkungan, juga kemampuan dalam memecahkan masalah-masalah lingkungan. Kemampuan mahasiswa dalam memecahkan masalah lingkungan diyakini akan menjadi dasar yang kuat untuk bertindak secara hatihati terutama ketika mahasiswa merespon berbagai aktivitas konsumtif terhadap berbagai produk teknologi yang semakin marak.

Sehubungan dengan hal tersebut, tidak dapat dipungkiri maka dalam proses perkuliahan harus dapat diciptakan suasana belajar yang mampu mendorong mahasiswa berpikir kreatif dan lebih berakar dari persoalan faktual dari kehidupan sehari-hari. Perkuliahan pendidikan lingkungan di perguruan tinggi harus dilihat dari kondisi internal mahasiswa agar dapat mengalami perubahan pengalaman kognitifnya. Salah satu faktor internal tersebut adalah gaya kognitif. Gaya kognitif yang terdiri atas dua, yaitu: independent dan dependent memiliki karakteristik yang berbeda di dalam hal memproses informasi dari pembelajaran. Masingmasing gaya kognitif memerlukan dukungan yang berbeda agar dapat diperoleh hasil pembelajaran yang maksimal.

Dengan pendekatan pembelajaran terintegratif untuk materi Pendidikan Lingkungan Hidup (PLH) di perguruan tinggi yaitu dalam mata Kuliah Kimia Dasar, maka dimungkinkan akan lebih merampingkan mata kuliah yang ada dalam kurikulum Jurusan Kimia.

Di samping itu, secara substansi pengetahuan tentang lingkungan akan diperkaya oleh materi pokok dari Kimia Dasar.

Di dalam penelitian, aspek kemampuan mahasiswa memecahkan masalah lingkungan dipengaruhi oleh banyak faktor. Faktor-faktor tersebut dapat berasal dari mahasiswa itu sendiri maupun di luar mahasiswa. Faktor-faktor dari diri mahasiswa yang berpotensi mempengaruhi kemampuan memecahkan masalah lingkungan antara lain persepsi, minat, bakat, motivasi, gaya kognitif, dan sebagainya. Faktor lain berasal dari luar mahasiswa yang tidak kalah penting, antara lain: materi kuliah, strategi pembelajaran, paket pem-belajaran, sarana fisik, latar belakang keluarga, nilai-nilai budaya, dan sebagainya. Keseluruhan faktor tersebut sangat menarik untuk dikaji lebih jauh terutama tentang pengaruhnya terhadap kemampuan mahasiswa memecahkan masalah lingkungan.

\section{METODE PENELITIAN}

Secara khusus tujuan penelitian ini untuk memperoleh gam-baran secara empirik tentang: (1) Perbedaan kemampuan mahasiswa memecahkan masalah lingkungan antara yang memperoleh paket pembelajaran PLH terintegratif dan mahasiswa yang memperoleh paket pembelajaran monolitik, (2) Perbedaan kemampuan mahasiswa memecahkan masalah lingkungan anatara yang memiliki gaya kognitif field independent dan mahasiswa yang memiliki gaya kognitif field dependent, (3) Pengaruh interaksi antara paket pembelajaran PLH dan gaya kognitif terhadap kemampuan mahasiswa memecahkan masalah

\begin{tabular}{l|l} 
Volume XIII & Nomor 01
\end{tabular}

Maret 2012

ISSN 1411-1829 
lingkungan, (4) Perbedaan kemampuan mahasiswa memecahkan masalah lingkungan yang memiliki gaya kognitif field independent yang memperoleh paket pembelajaran PLH terintegratif dan mahasiswa memperoleh paket pembelajaran PLH monolitik, dan (5) Perbedaan kemampuan mahasiswa memecahkan masalah lingkungan yang memiliki gaya kognitif field dependent yang memperoleh paket pembelajaran PLH terintegratif dan mahasiswa memperoleh paket pembelajaran PLH monolitik.

Pelaksanaan penelitian ini adalah Jurusan Kimia, FMIPA, Universitas Negeri Jakarta. Adapun waktu penelitian adalah bulan Juli sampai dengan Oktober 2011.

Penelitian ini menggunakan metode eksperimen dengan disain faktorial 2x2. Disain penelitian dapat digambarkan sebagai berikut:

Tabel 1. Desain Penelitian 2 x 2 Faktorial

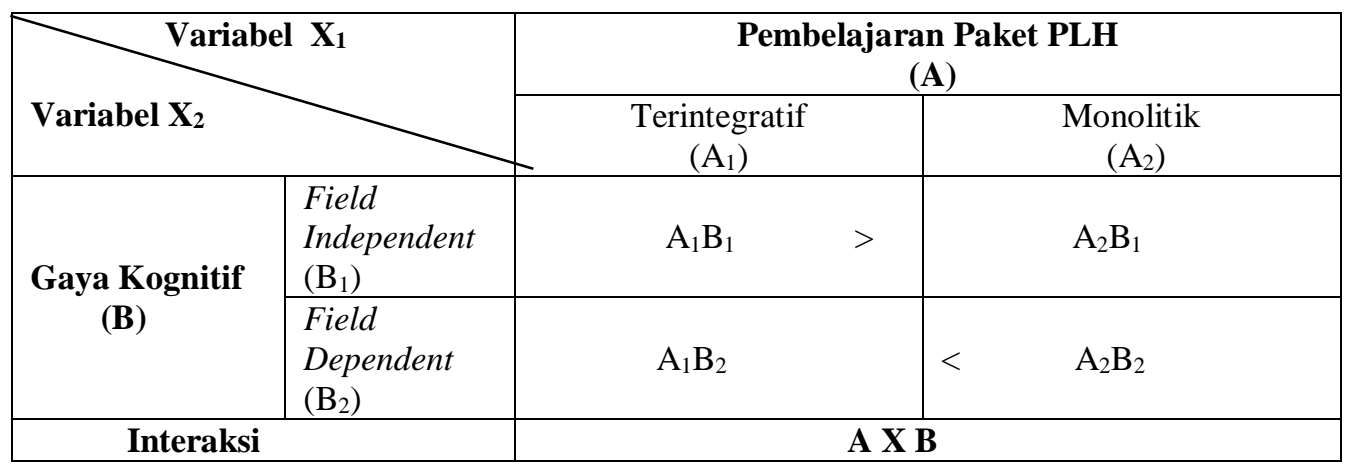

Populasi dalam penelitian ini adalah mahasiswa Jurusan Kimia, FMIPA, Universitas Negeri Jakarta. Sampel penelitian ditetapkan sebanyak 2 kelas. Kedua kelas tersebut terdiri atas mahasiswa kelas A (jumlah 39 orang) dan mahasiswa kelas B (jumlah 37 orang).

Untuk kepentingan analisis data, maka sampel yang dianalisis adalah 27\% ranking atas dan $27 \%$ ranking bawah dari hasil pengukuran gaya kognitif. Pertimbangan ini di dasarkan kepada konsep daya pembeda sebagaimana dikemukakan Kelley yang dikutip oleh Nur (1987: 139), bahwa penetapan proporsi $27 \%$ sebagai kelompok atas (high level) dan proporsi $27 \%$ sebagai kelompok bawah (low level) ini merupakan pemisahan berdasarkan kriteria internal berupa ranking skor mempunyai indeks diskriminasi (daya pembeda) yang lebih sensitif dan stabil.

Dengan pertimbangan tersebut maka sampel yang dianalisis untuk masing-masing sel dalam disain eksperimen faktorial $2 \times 2$ adalah 10 responden. Ini berarti sampel yang digunakan dalam penelitian ini berjumlah 40 orang mahasiswa.

Pengumpulan data dalam penelitian ini menggunakan instrumen yang pengembangannya dilakukan uji coba instrument. Hasil uji coba berupa harga validitas butir dihitung dengan rumus korelasi product moment dari Pearson dan harga koefisien reliabilitas hasil pengukuran dihitung dengan rumus

\begin{tabular}{|l|l|l|l|}
\hline Volume XIII & Nomor 01 & Maret 2012 & ISSN 1411-1829 \\
\hline
\end{tabular}


alpha-Cronbach. Secara keseluruhan hasil uji coba instrumen sebagai berikut:

Tabel 2. Rangkuman Hasil Uji Coba Instrumen Pengukuran Kemampuan Memecahkan Masalah Lingkungan

\begin{tabular}{|c|l|c|l|}
\hline No & \multicolumn{1}{|c|}{ Uji } & Hasil & \multicolumn{1}{c|}{ Keterangan } \\
\hline 1. & $\begin{array}{l}\text { Validitas } \\
\text { Instrumen }\end{array}$ & 17 butir valid & $\begin{array}{l}\text { Butir yang dinyatakan drop berjumlah 8 buah, } \\
\text { yakni: nomor 2; 5; 9; 12; 13; 14; 19; dan 23. }\end{array}$ \\
\hline 2. & $\begin{array}{l}\text { Reliabilitas } \\
\text { Instrumen }\end{array}$ & 0,85 & Harga r dihitung dari 17 butir yang valid \\
\hline
\end{tabular}

Instrumen yang digunakan untuk mengukur gaya kognitif adalah instrumen baku yang telah diijinkan oleh pengembangnya Prof. Dr. I Nyoman Degeng. Dengan instrumen baku tersebut, maka penuilis tidak melakukan uji coba instrumen khusus untuk instrumen gaya kognitif.

\section{HASIL PENELITIAN}

\section{Kemampuan}

Memecahkan

Mahasiswa

Masalah

Lingkungan yang Memperoleh Paket Pembelajaran PLH

Terintegratif dan Memiliki Gaya Kognitif Field Independent

Deskripsi hasil penelitian yang berupa skor kemampuan mahasiswa memecahkan masalah lingkungan yang memperoleh paket pembelajaran PLH terintegratif dan memiliki gaya kognitif field independent $\left(\mathrm{A}_{1} \mathrm{~B}_{1}\right)$ mencakup harga-harga statistik deskriptif dihitung melalui sampel berjumlah 10 responden. Harga statistik deskriptif yang dihitung antara lain: mean $=47,50$ median $=47,50$ dan modus $=47,00$ Harga simpangan baku 1,354.

Ketiga harga gejala pusat dari (mean, median, dan modus) di atas ternyata tidak sama besar. Keadaan ini berimbas pada kurva distribusi normal populasi penelitian ini tidak simetris. Seperti dikemukakan oleh Furqon (2009: 47), bahwa jika distribusi data simetris, maka modus, median, dan mean sama besar. Namun demikian, karena hargaharga median dan mean selisihnya sangat kecil dan sifatnya lebih stabil dibandingkan modus berarti data masih mendekati simetris.

\section{Kemampuan Mahasiswa Me- mecahkan Masalah Lingkungan yang memperoleh Paket Pem- belajaran PLH Monolitik dan Memiliki Gaya Kognitif Field Independent \\ Deskripsi hasil penelitian yang} berupa skor kemampuan mahasiswa memecahkan masalah lingkungan yang memperoleh paket pembelajaran PLH monolitik dan memiliki gaya kognitif field independent $\left(\mathrm{A}_{2} \mathrm{~B}_{1}\right)$ mencakup harga-harga statistik des-kriptif dihitung melalui sampel ber-jumlah 10 responden. Harga statistik deskriptif yang dihitung, antara lain: mean $=47,10$ median $=47,0$ dan modus $=49,00$ Harga simpangan baku 1,853.

Ketiga harga gejala pusat dari (mean, median, dan modus) di atas ternyata tidak sama besar. Keadaan ini berimbas pada kurva distribusi normal populasi penelitian ini tidak simetris. Namun demikian, karena harga-harga median dan mean selisihnya sangat kecil

\begin{tabular}{|l|l|l|l|}
\hline Volume XIII & Nomor 01 & Maret 2012 & ISSN 1411-1829 \\
\hline
\end{tabular}


dan sifatnya lebih stabil dibandingkan modus berarti data masih mendekati simetris.

3. Kemampuan Mahasiswa Memecahkan Masalah Lingkungan yang Memperoleh Paket Pembelajaran PLH Terintegratif dan Memiliki Gaya Kognitif Field Independent

Deskripsi hasil penelitian yang berupa skor kemampuan mahasiswa memecahkan masalah lingkungan yang memperoleh paket pembelajaran PLH terintegratif dan memiliki gaya kognitif field independent $\left(\mathrm{A}_{1} \mathrm{~B}_{2}\right)$ mencakup harga-harga statistik des-kriptif dihitung melalui sampel berjumlah 10 responden. Harga sta-tistik deskriptif yang dihitung antara lain: mean $=46,30$ median $=46,50$ dan modus $=48,00$ Harga simpangan baku 1,636.

Ketiga harga gejala pusat dari (mean, median, dan modus) di atas ternyata tidak sama besar. Keadaan ini berimbas pada kurva distribusi normal populasi penelitian ini tidak simetris. Namun demikian, karena harga-harga median dan mean selisihnya sangat kecil dan sifatnya lebih stabil dibandingkan modus berarti data masih mendekati simetris.

4 Kemampuan Mahasiswa Memecahkan Masalah Lingkungan yang Memperoleh Paket Pembelajaran PLH Monolitik dan Memiliki Gaya Kognitif Field Dependent
Deskripsi hasil penelitian yang berupa skor kemampuan mahasiswa memecahkan masalah lingkungan yang memperoleh paket pembelajaran PLH monolitik dan memiliki gaya kognitif field dependent $\left(\mathrm{A}_{2} \mathrm{~B}_{2}\right)$ mencakup hargaharga statistik deskriptif dihitung melalui sampel berjumlah 10 responden. Harga statistik deskriptif yang dihitung antara lain: mean $=46,80$ median $=47,00$ dan modus $=47,00$ Harga simpangan baku 2,299.

Ketiga harga gejala pusat dari (mean, median, dan modus) di atas ternyata tidak sama besar. Keadaan ini berimbas pada kurva distribusi normal populasi penelitian ini tidak simetris. Namun demikian, karena harga-harga median dan mean selisihnya sangat kecil dan sifatnya lebih stabil dibandingkan modus berarti data masih mendekati simetris.

\section{Persyaratan Uji Hipotesis \\ Uji Normalitas Data}

Persyaratan uji hipotesis berkenaan dengan asumsi dasar bahwa penggunaan teknik analisis menggunakan statistika parametrik dalam analisis data ini adalah meliputi uji normalitas data. Uji normalitas data berdasarkan data sampel yang telah diukur untuk masing-masing variabel penelitian. Berdasarkan hasil perhitungan uji normalitas data dengan menggunakan Kolmogorov Smirnov memberikan hasil sebagai berikut:

60

\begin{tabular}{|l|l|l|l|}
\hline Volume XIII & Nomor 01 & Maret 2012 & ISSN 1411-1829 \\
\hline
\end{tabular}


Tabel 3. Ringkasan Hasil Uji Normalitas Data dengan Menggunakan Rumus Kolmogorov Smirnov One Sample

\begin{tabular}{|c|c|c|c|c|}
\hline No & $\begin{array}{c}\text { Kelompok } \\
\text { Data }\end{array}$ & $\begin{array}{c}\text { Harga Sig. } \\
\text { Kolmogorov } \\
\text { Smirnov }\end{array}$ & Harga $\alpha$ & Kesimpulan \\
\hline 1. & $\mathrm{~A}_{1}$ & 0,619 & \multirow{8}{*}{0,05} & \multirow{8}{*}{$\begin{array}{l}\text { Dari delapan kelompok } \\
\text { data penelitian, harga sig. } \\
\text { Kolmogorov Smirnov } \\
0,05 \text {. Ini berarti terima } \\
\text { Ho, maka dapat } \\
\text { disimpul-kan data } \\
\text { berdistribusi normal. }\end{array}$} \\
\hline 2. & $\mathrm{~A}_{2}$ & 0,819 & & \\
\hline 3. & $\mathrm{~B}_{1}$ & 0,819 & & \\
\hline 4. & $\mathrm{~B}_{2}$ & 0,476 & & \\
\hline 5. & $\mathrm{~A}_{1} \mathrm{~B}_{1}$ & 0,543 & & \\
\hline 6. & $\overline{A_{1} B_{2}}$ & 0,961 & & \\
\hline 7. & $\mathrm{~A}_{2} \mathrm{~B}_{1}$ & 0,946 & & \\
\hline 8. & $\mathrm{~A}_{2} \mathrm{~B}_{2}$ & 0,241 & & \\
\hline
\end{tabular}

\section{Uji Homogenitas Varians}

Dalam uji ini dihitung varians masing-masing variabel bebas dibandingkan dengan varibel terikat. Berdasarkan hasil perhitungan uji homogenitas dengan menggunakan Levene Statistic, dimana kelompok data $\mathrm{A}_{1} \mathrm{~B}_{1}$ ditempatkan sebagai faktor pembanding, maka diperoleh hasil uji sebagai berikut:

1) Untuk data $A_{1} B_{2}$, diperoleh harga Sig. Levene statistics $=0,111>$ $\alpha=0,05$. Hasil ini menunjukkan terima Ho pada $\alpha=0,05$ yang berarti varians populasi dalam penelitian ini sama atau homogen.

2) Untuk data $A_{2} B_{1}$, diperoleh harga Sig. Levene statistics $=0,114>$ $\alpha=0,05$. Hasil ini menunjukkan terima Ho pada $\alpha=0,05$ yang berarti varians populasi dalam penelitian ini sama atau homogen.
Untuk data $\mathrm{A}_{1} \mathrm{~B}_{2}$, diperoleh harga Sig. Levene statistics $=0,218>\alpha=0,05$. Hasil ini menunjukkan terima Ho pada $\alpha=0,05$ yang berarti varians populasi dalam penelitian ini sama atau homogen. Berdasarkan pengujian persyaratan uji hipotesis di atas, yaitu baik normalitas data maupun homogenitas varians yang digunakan dalam penelitian ini terpenuhi, maka uji hipotesis dengan menggunakan Anava Dua Arah dapat dilanjutkan.

\section{Pengujian Hipotesis \\ Hipotesis Pertama}

Uji hipotesis pertama dimaksudkan untuk menguji apakah benar adanya bahwa, "kemampuan mahasiswa memecahkan masalah lingkungan yang memperoleh paket pembelajaran PLH terintegratif $\left(\mathrm{A}_{1}\right)$ lebih tinggi dari pada mahasiswa yang memperoleh paket pembelajaran PLH monolitik $\left(\mathrm{A}_{2}\right)$ ”. Kriteria uji yang digunakan adalah tolak Ho jika harga $F_{\text {hitung }}>\mathrm{F}_{\text {tabel }}$ pada taraf signifikansi $(\alpha=0,05)$.

61

\begin{tabular}{|l|l|l|l|}
\hline Volume XIII & Nomor 01 & Maret 2012 & ISSN 1411-1829 \\
\hline
\end{tabular}


Hasil perhitungan uji Anava Dua Arah dirangkum dalam tabel berikut:

Tabel 4 Ringkasan Hasil Uji Anava Dua Arah Pengaruh Paket Pembelajaran
PLH dan Gaya Kognitif terhadap Kemampuan Memecahkan Masalah
Lingkungan

\begin{tabular}{|l|c|c|c|c|c|c|}
\hline & dk & JK & \multirow{2}{*}{ RJK } & \multirow{2}{*}{ F $_{\text {hit }}$} & \multicolumn{2}{|c|}{ F } \\
\cline { 5 - 7 } & & & & & $\alpha=0,05$ & $\alpha=0,01$ \\
\hline Model Terkoreksi & 3 & 48,400 & 16,133 & & & \\
\hline Intersep & 1 & 87609,600 & 87609,600 & & & \\
\hline Paket Pemb. PLH (A) & 1 & 14,400 & 14,400 & $5,76^{*)}$ & 2,08 & 7,31 \\
\hline Gaya Kognitif (B) & 1 & 1,600 & 1,600 & $\left.0,64^{*}\right)$ & 2,08 & 7,31 \\
\hline Int. A x B & 1 & 32,400 & 32,400 & $12,96^{* *)}$ & 2,08 & 7,31 \\
\hline Kekeliruan & 36 & 90,000 & 2,500 & & & \\
\hline Total & 40 & 87748,000 & - & & & \\
\hline Koreksi Total & 39 & 138,400 & - & & & \\
\hline
\end{tabular}

\section{Keterangan:}

$\mathrm{dk}=$ derajat kebebasan .

$\mathrm{JK}=$ Jumlah kuadrat.

B = Gaya Kognitif

RJK = Rerata Jumlah Kuadrat.

Int. = Interaksi.

A $\quad$ Paket Pembelajaran PLH

$*)$ Signifikan pada $\alpha=0,05$.

$* *)=$ Sangat signifikan pada $\alpha=0,01$.

Harga $F_{\text {tabel }}$ diperoleh sebagai berikut $\mathrm{F}_{(0,05)(36)}=2,08$. Sedangkan untuk $\alpha=0,01$ diperoleh harga $F_{(0,01)(36)}=7,31$. Dari ringkasan uji pada Tabel 4.7 (kolom sumber variasi pada baris Paket Pemb PLH) memberikan hasil bahwa $F_{\text {hitung }}=$ $5,76>F_{(0,05)(36)}=2,08$. Hasil uji menunjukkan $F_{\text {hitung }}$ lebih besar dari $F_{\text {tabel }}$ berarti tolak Ho pada $\alpha=0,05$.

Hasil uji ini memberikan bukti secara empirik bahwa "kemampuan mahasiswa memecahkan masalah lingkungan yang memperoleh paket pembelajaran PLH terintegratif lebih tinggi dari pada mahasiswa yang memperoleh paket pembelajaran monolitik” adalah signifikan.

Dengan hasil uji hipotesis pertama di atas, ini berarti dengan tidak memperhitungkan gaya kognitif dalam pembelajaran PLH, menunjuk-kan adanya pengaruh paket pem-belajaran PLH terhadap kemampuan mahasiswa memecahkan masalah lingkungan. Dalam hal ini dengan memberikan paket pembelajaran PLH terintegratif maka kemampuan maha-siswa dalam memecahkan masalah lingkungan akan lebih baik.

Kenyataan ini didukung bukti bahwa kemampuan mahasiswa memecahkan masalah lingkungan yang memperoleh paket pembelajaran PLH terintegratif lebih tinggi dari pada mahasiswa yang memperoleh paket pembelajaran monolitik.

\section{Hipotesis Kedua}

Pengujian hipotesis kedua dengan menggunakan uji Anava Dua Arah adalah untuk menguji pengaruh simple effect yakni pengaruh gaya kognitif terhadap kemampuan me-mecahkan masalah lingkungan. Hipotesis statistik yang diuji adalah:

$\mathrm{H}_{0}: \mu_{\mathrm{B} 1} \leq \mu_{\mathrm{B} 2}$

$\mathrm{H}_{1}: \mu_{\mathrm{B} 1}>\mu_{\mathrm{B} 2}$

Uji hipotesis kedua dimaksudkan untuk menguji apakah benar adanya bahwa, "kemampuan maha-siswa

\begin{tabular}{|l|l|l|l|}
\hline Volume XIII & Nomor 01 & Maret 2012 & ISSN 1411-1829 \\
\hline
\end{tabular}


memecahkan masalah ling-kungan yang memiliki gaya kognitif field independent lebih tinggi dari pada yang memiliki gaya kognitif field dependent”.

Dengan kriteria uji yang digunakan dalam uji hipotesis ini adalah tolak Ho jika harga $F_{\text {hitung }}>F_{\text {tabel. }}$ Di mana harga $F_{\text {tabel }}$ diperoleh sebesar $\mathrm{F}_{(0,05)(1: 36)}=2$,08. Sedangkan untuk $\alpha=$ 0,01 diperoleh harga $F_{(0,01)(1: 36)}=7,31$.

Berdasarkan hasil perhitungan uji Anava Dua Arah yang diringkas dalam Tabel 4.6 (sumber variasi pada baris gaya kognitif) di atas diperoleh harga $F_{\text {hitung }}=0,640<F_{(0,05)(1: 36)}=2,08$. Hasil uji menunjukkan $F_{\text {hitung }}$ lebih kecil dari $F_{\text {tabel }}$ berarti terima Ho pada $\alpha=0,05$. Dengan demikian hasil uji memberikan bukti secara empirik bahwa "kemampuan mahasiswa memecahkan masalah lingkungan yang memiliki gaya kognitif field independent lebih tinggi dari pada mahasiswa yang memiliki gaya kognitif field dependent" adalah tidak signifikan.

Dengan hasil uji hipotesis kedua di atas, maka diperoleh kenyataan bahwa tinggi rendahnya kemampuan mahasiswa memecahkan masalah lingkungan tidak dipengaruhi oleh gaya kognitif. Hal ini dibuktikan dengan fakta hasil penelitian bahwa kemampuan mahasiswa memecahkan masalah lingkungan yang memiliki gaya kognitif field independent tidak lebih tinggi dari pada mahasiswa yang memiliki gaya kognitif field dependent.

\section{Hipotesis Ketiga}

Pengujian hipotesis ketiga dengan menggunakan uji Anava Dua Arah adalah untuk menguji pengaruh interaksi antara paket pembelajaran PLH (A) dan gaya kognitif (B). Hipo-tesis statistik yang diuji adalah
$\mathrm{H}_{0}$ : Int. $\mathrm{A} \times \mathrm{B}=0$

$\mathrm{H}_{1}$ : Int. $\mathrm{A} \times \mathrm{B} \neq 0$

Uji hipotesis ketiga dimaksudkan untuk menguji apakah benar adanya bahwa, "terdapat pengaruh interaksi antara paket pembelajaran PLH dan gaya kognitif terhadap kemampuan mahasiswa memecahkan masalah lingkungan”.

Dengan menggunakan kriteria uji terima Ho jika harga $-\mathrm{F}_{\text {tabel }}<\mathrm{F}_{\text {hitung }}<$

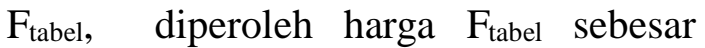
$F_{(0,05)(1: 36)}=2,08$. Sedangkan untuk $\alpha=$ 0,01 diperoleh harga $F_{(0,01)(1: 36)}=7,31$. Berdasarkan hasil uji yang diringkas dalam Tabel 4.6 (kolom sumber variasi pada baris Int. A x B) dapat diperoleh kenyataan bahwa $-\mathrm{F}_{(0,05)(1: 36)}=-2,08<$ $F_{\text {hitung }}=12,96>F_{(0,05)(1: 36)}=2,08$. Hasil uji memberikan harga $F_{\text {hitung }}$ berada di luar daerah penerimaan Ho, berarti tolak Ho pada $\alpha=0,05$.

Hasil uji ini memberikan bukti secara empirik bahwa "terdapat pengaruh interaksi antara paket pembelajaran PLH dan gaya kognitif terhadap kemampuan mahasiswa memecahkan masalah lingkungan” ada-lah signifikan.

Dengan hasil uji hipotesis ketiga di atas, berarti tinggi rendahnya kemampuan mahasiswa dalam memecahkan masalah lingkungan ditentukan oleh gaya kognitif mahasiswa. Dalam hal ini dapat dijelaskan sebagai berikut:

Pertama, kemampuan mahasiswa memecahkan masalah ling-kungan pada paket pembelajaran PLH terintegratif lebih tepat diberikan kepada mahasiswa yang memiliki gaya kognitif field independent. Hal ini didukung bukti bahwa pada mahasiswa yang memiliki gaya kognitif field independent yang memperoleh paket pem-belajaran PLH

63

\begin{tabular}{l|l} 
Volume XIII & Nomor 01
\end{tabular}

Maret 2012

ISSN 1411-1829 
terintegratif lebih tinggi dari pada mahasiswa yang memperoleh paket pembelajaran PLH monolitik.

Kedua, kemampuan mahasiswa memecahkan masalah lingkungan pada paket pembelajaran PLH monolitik lebih tepat diberikan kepada mahasiswa yang memiliki gaya kognitif field dependent. Hal ini didukung bukti bahwa pada mahasiswa yang memiliki gaya kognitif field dependent yang memperoleh paket pembelajaran PLH terintegratif tidak lebih tinggi dari pada mahasiswa yang memperoleh paket pembelajaran PLH monolitik.

Dengan hasil uji ketiga yang memberikan hasil terdapat pengaruh interaksi antara paket pembelajaran PLH dan gaya kognitif dapat digambarkan dalam grafik dengan estimasi harga ratarata kemampuan memecahkan masalah lingkungan sebagai berikut: 1) rata-rata skor kemampuan memecahkan masalah lingkungan pada mahasiswa dengan gaya kognitif field independent ( $\left.\mathrm{b}_{1}\right)$ pada sampel paket pembelajaran PLH terintegratif $\left(\mathrm{a}_{1}\right)=47,50$ dan pada sampel paket pembelajaran PLH monolitik $\left(\mathrm{a}_{2}\right)=$ 46,10; dan 2) rata-rata skor kemampuan memecahkan masalah lingkungan pada mahasiswa dengan gaya kognitif filed dependent $\left(\mathrm{b}_{2}\right)$ pada sampel paket pembelajaran PLH terintegratif $\left(\mathrm{a}_{1}\right)=$ 46,30 dan pada sampel paket pembelajaran PLH monolitik $\left(\mathrm{a}_{2}\right)=$ 46,800 .

\section{Hipotesis Keempat}

Pengujian hipotesis keempat dengan menggunakan uji Tukey adalah untuk menguji pengaruh faktor gaya kognitif field independent dalam eksperimen dengan menggunakan paket pembelajaran PLH terintegratif dan paket pembelajaran PLH monolitik. Hipotesis statistik yang diuji adalah:

$\mathrm{H}_{0}: \mu_{\mathrm{A} 1 \mathrm{~B} 1} \leq \mu_{\mathrm{A} 2 \mathrm{~B} 1}$

$\mathrm{H}_{1}: \mu_{\mathrm{A} 1 \mathrm{~B} 1}>\mu_{\mathrm{A} 2 \mathrm{~B} 1}$

Uji hipotesis keempat dimaksudkan untuk menguji apakah benar bahwa, "kemampuan mahasiswa me-mecahkan masalah lingkungan yang memiliki gaya kognitif field independent yang memperoleh paket pembelajaran PLH terintegratif lebih tinggi dari pada yang memperoleh paket pembelajaran PLH monolitik”.

Pengujian hipotesis keempat sebagai tindak lanjut adanya pengaruh interaksi antara paket pembelajaran PLH dan gaya kognitif terhadap kemampuan memecahkan masalah lingkungan digunakan uji post hoc Tukey. Hasil uji post hoc Tukey diperoleh Qhitung $=26,129$ $>\mathrm{Q}_{(0,01)(1: 36)}=7,31$. Harga Qhitung lebih besar dari Q tabel berarti tolak Ho pada $\alpha=$ 0,01 . Hasil uji ini memberikan bukti secara empirik bahwa "kemampuan mahasiswa memecahkan masalah lingkungan yang memperoleh paket pembelajaran PLH terintegratif dan memiliki gaya kognitif field independent lebih tinggi dari pada mahasiswa yang mem-peroleh paket pembelajaran PLH monolitik” adalah sangat signifikan.

Berdasarkan hasil uji hipotesis keempat di atas, dapat diperoleh temuan bahwa gaya kognitif field independent dan paket pembelajaran PLH berpengaruh terhadap kemampu-an mahasiswa memecahkan masalah lingkungan. Hal ini dibuktikan dengan adanya kenyataan bahwa kemampuan mahasiswa memecahkan masalah lingkungan yang memiliki gaya kognitif field independent yang memperoleh paket pembelajaran PLH terintegratif, lebih tinggi dari pada mahasiswa yang

64

Volume XIII

Nomor 01

Maret 2012

ISSN 1411-1829 
memperoleh paket pembelajaran PLH monolitik.

\section{Hipotesis Kelima}

Pengujian hipotesis kelima dengan menggunakan uji post hoc Tukey adalah untuk menguji pengaruh faktor gaya kognitif field dependent dalam eksperimen dengan menggunakan paket pembelajaran PLH terintegratif dan paket pembelajaran PLH monolitik. Hipotesis yang diuji adalah:

$\mathrm{H}_{0}: \mu_{\mathrm{A} 1 \mathrm{~B} 2} \geq \mu_{\mathrm{A} 2 \mathrm{~B} 2}$

$\mathrm{H}_{1}: \mu_{\mathrm{A} 1 \mathrm{~B} 2}<\mu_{\mathrm{A} 2 \mathrm{~B} 2}$

Pengujian hipotesis kelima sebagai tindak lanjut adanya pengaruh interaksi antara paket pembelajaran PLH dan gaya kognitif terhadap kemampuan memecahkan masalah lingkungan digunakan uji post hoc Tukey. Qhitung= $0,549<\mathrm{Q}_{(0,01)(1: 18)}=4,41$. Harga $\mathrm{Q}_{\text {hitung }}$ lebih kecil dari Qtabel berarti terima Ho pada $\alpha=0,05$. Hasil uji ini memberikan bukti secara empirik bahwa "kemampuan mahasiswa memecahkan masalah lingkungan yang memiliki gaya kognitif field dependent yang memperoleh paket pembelajaran PLH terintegratif lebih rendah dari pada mahasiswa yang memperoleh paket pembelajaran PLH monolitik” adalah tidak signifikan.

Berdasarkan hasil uji hipotesis kelima di atas, dapat diperoleh temuan bahwa gaya kognitif field dependent dan paket pembelajaran PLH berpengaruh terhadap kemampuan mahasiswa memecahkan masalah lingkungan. Hal ini dibuktikan dengan adanya kenyataan bahwa kemampuan mahasiswa memecahkan masalah lingkungan yang memiliki gaya kognitif field dependent yang memperoleh paket pembelajaran PLH terintegratif, tidak lebih tinggi dari pada mahasiswa yang memperoleh paket pembelajaran PLH monolitik.

\section{Pembahasan Hasil Penelitian}

Hasil penelitian yang dianalisis berdasarkan hasil uji hipotesis seperti telah diuraikan di atas dapat diperoleh bahwa dari kelima hipotesis empat hipotesis seluruhnya teruji. Hanya hipotesis kedua yaitu hipotesis simple effect yang tidak teruji. Hasil uji hipotesis kedua gagal menolak Ho, yang dalam hal ini kemampuan mahasiswa memecahkan masalah lingkungan yang memiliki gaya kognitif field independent tidak lebih tinggi dari pada mahasiswa yang memiliki gaya kognitif field dependent. Hal Ini berarti bahwa gaya kognitif tidak menentukan ada tidaknya perbedaan kemampuan mahasiswa memecahkan masalah lingkungan.

Berkenaan dengan temuan hasil uji hipotesis kedua, maka dapat dijelaskan bahwa didalam penelitian ini sampel yang diteliti adalah mahasiswa Jurusan Kimia dengan latar belakang pendidikan yang homogen yaitu mahasiswa yang sudah terbentuk pola belajarnya sebagai calon saintis IPA. Kondisi ini dimungkinkan dapat menyebabkan perbedaan gaya kognitif secara mendasar cenderung tipis.

Seperti dijelaskan oleh Western (1996: 17), di dalam sistem kognitif yang dapat digunakan sebagai jawaban pertanyaan dan pemecahan masalah. bila seseorang sedang berfilsafat tentang dunia sosial, maka aktivitas kemampuan koginitif relatif tinggi. Konsepsi tersebut dapat dipahami bahwa dalam lingkup latar belakang yang sama maka kemampuan kognitif yang dalam hal ini adalah kemampuan memecahkan masalah cenderung berada dalam tingkat yang sama. Ini berarti penelitian ini dari

65

\begin{tabular}{|l|l|l|l|}
\hline Volume XIII & Nomor 01 & Maret 2012 & ISSN 1411-1829 \\
\hline
\end{tabular}


aspek sampel terdapat tingkat keseragaman yang tinggi. Dengan latar belakang mahasiswa satu jurusan yaitu Jurusan Kimia maka pola berpikir yang terbentuk pada dasarnya sama. Determinasi kemampuan berpikir dalam memecahkan masalah pun cenderung sama.

Kemungkinan lain yang menyebabkan gaya kognitif tidak menentukan ada tidaknya perbedaan kemampuan mahasiswa memecahkan masalah lingkungan adalah populasi yang terjangkau jumlahnya kecil. Dengan demikian untuk terjadinya perbedaan signifikan gaya kognitif dari populasi terjangkau peluangnya relatif kecil.

Namun demikian, dilain pihak hasil penelitian ini memberikan penguatan bahwa secara empirik fakta yang diungkap mengenai kemampuan mahasiswa memecahkan masalah lingkungan didasarkan pada dua faktor yaitu paket pembelajaran PLH dan gaya kognitif tidak bertentangan dengan konsep-konsep yang digunakan untuk membangun kerangka berpikir dalam penelitian ini.

Dengan demikian, hasil penelitian ini diharapkan dapat memberikan sumbangan guna memperkaya khaza-nah pengetahuan ilmiah terutama dalam studi pengaruh paket pem-belajaran PLH dan gaya kognitif ter-hadap kemampuan mahasiswa me-mecahkan masalah lingkungan.

\section{KESIMPULAN}

Berdasarkan hasil analisis dan pembahasan yang telah diuraikan dalam penelitian ini dapat diperoleh temuantemuan sebagai berikut:
Pertama, kemampuan mahasiswa memecahkan masalah lingkungan yang memperoleh paket pembelajaran PLH terintegratif lebih tinggi dari pada mahasiswa yang memperoleh paket pembelajaran PLH monolitik.

Kedua, kemampuan maha-siswa memecahkan masalah ling-kungan yang memiliki gaya kognitif field independent tidak lebih tinggi dari pada gaya kognitif field dependent.

Ketiga, terdapat pengaruh interaksi antara paket pembelajaran PLH dan gaya kognitif terhadap kemampu-an mahasiswa memecahkan masalah lingkungan.

Keempat, kemampuan mahasiswa memecahkan masalah lingkung-an yang memiliki gaya kognitif field independent yang memperoleh paket pembelajaran PLH terintegratif lebih tinggi dari pada mahasiswa yang memperoleh paket pembelajaran PLH monolitik.

Kelima, kemampuan mahasis-wa memecahkan masalah lingkungan yang memiliki gaya kognitif field dependent yang memperoleh pembelajaran paket PLH terintegratif lebih rendah dari pada mahasiswa yang memperoleh paket pembelajaran PLH monolitik.

Berdasarkan paparan temuan di atas, maka dapat disimpulkan bahwa tidak ada pengaruh paket pembelajaran PLH terhadap kemampuan mahasiswa memecahkan masalah lingkungan yang paling efektif. Tinggi rendahnya kemampuan memecahkan masalah lingkungan ditentukan oleh gaya kognitif mahasiswa. Paket pembelajaran PLH terintegratif akan berpengaruh lebih baik terhadap kemampuan memecahkan masalah lingkungan apabila diberikan kepada mahasiswa yang memiliki gaya

66

\begin{tabular}{l|l} 
Volume XIII & Nomor 01
\end{tabular}

Maret 2012

ISSN 1411-1829 
kognitif field independent. Sebaliknya paket pembelajaran PLH monolitik akan berpengaruh lebih baik terhadap kemampu-an memecahkan masalah lingkungan apabila diberikan kepada mahasiswa yang memiliki gaya kognitif field dependent.

\section{DAFTAR PUSTAKA}

Aiken, Lewis R. Psychological testing and Assessment Boston: Allynand,1997.

Asyik, Buchori. "Penyusunan Modul Pendidikan Lingkungan Hidup Untuk Siswa SD, SMP, dan SMA. 2009.” http://blog. unila.ac.id/buchoriasyik/ 2009/07/30/penyusunan-modulpendidikan-lingkung-an-hidupuntuk-siswa-sd-smp-dan-sma1/.(diakses,15 Agustus 2011).

Bruner. J. C., Goodnow, J.J., dan Austin, G. E. A Study of Thinking. New York: Wiley, 1956.

Carin, Arthur A. Guided Discivery Activities for Elementary School Science. Columbus, Ohio: Merrill Publishing Company, 1997.

Carin, Arthur A. dan Robert B. Sund, Teaching Science Through Discovery. Columbus. Ohio: Merrill Publishing Company, 1989.

Charles, C. M. Individualizing Instruction. St. Louis: The C.V. Mosby Company, 1980.

Davis Keith dan John W. Newstrom. Organization Behavior Hu-man Behavior at Work. New York: McGraw Hill, 1993.

Dworetzky, Jhon P. Psychology. New York: West Publishing Compa-ny, 1988.
Eugene P. Odum. Fundamentals of Ecology. United State of America: W.B Saunders Company, 1971.

Gagne, Robert M. The Condition of Learning. New York: Hort Rinnehart and Winston Inc., 1977.

Gagne, Robert M., Briggs L. J., dan Wager, W. W. Principles of Instructional, Third Edition. New York: Holt, Reinhart, \& Winston, 1988.

Gagne, Robert M. (Ed.). Instructional Technology Foundations. Hillsdale, NJ: Lawrence Erlbaum Associates, 1987.

Goldstein, Norman L., dan E Brophy, Education Psycholog. New York: Longman. 1990.

http://www.cartridgerescue.com.au/Envi ronment/The_4_R_s_of_Envirome ntal_Management.aspx.(diakses, 23 Juli 2011)

Jerold, W. APPS. Study Skill for Today's College Student. USA: McGrawHill, Inc., 1990.

Lasmahadi, Arbono. "Pemecahan Masalah Secara Analitis dan Kreatif”. (http://www.epsikologi.com/epsi/Industri_detail.as p?id), 2005. (diakses, 10 Agustus 2011).

Miller and Taylor. Living in The Environmental: An Introduction to Environmental Science. California: Beirmont, 1986.

Moran, Aida. The Phychology of Concentration in Sport. UK and Francis: Psychology Press, 1996.

Nasution, S. Berbagai Strategi dalam Proses Belajar dan Me-ngajar. Jakarta: Bumi Aksara, 1997.

Olson, Matthew H. dan B.R. Hergenhahn. An Introduction to Theories of Learning. Pear-son Prentice Hall, Inc., 2008. 
Putrawan, I Made. Pengujian Hipotesis dalam Penelitian-penelitian Sosial. Jakarta: Rineka Cipta, 1990.

Robbins, Stepen P. Essential of Organizational Behavior. New Jersey: Prentice Hall Inter-national Inc., 1997.

Schermerhorn, G. Hunt., dan Obsborn, Organizational Behavior. USA: John Wiley \& Sons, Inc., 2003.

Sumardyono, "Pengertian Dasar Problem Solving”, (http:// 74. 125.153.132/search?q=cache:Bgx604YmG7YJ:p4tkmatemati ka.org).(diakses, 23 Juli 2011).

Stamovlasis, Dimitrios and Georgios Tsaparlis, "Cognitive Variables in Problem Solving: a Nonlinear Approach," Inter-national Journal of Science and Mathematics Education, National Science Council, Vol. 3. Taiwan 2005, p. 7.

Taconis, R., Ferguson Hessler., dan Broekkamp, "Teaching Science Problem Solving: an Overview of Experimental Work Graduate School of Te-aching and Learning," Journal of Research in Science Te-aching., University of Amster-dam, The Netherlands Vol. 38, No. 4, 2001., p. 442.
Tivy, Joy dan Greg O’Hare, Human Impact on Ecosystem. Edin-burg and New York: Oliver \& Boyd, 1985.

Volk, H. R. T. L., Hungerford., dan J. M. Ramsey, Science Techno-logy Society: Investigating and Evaluating STS Issues and Solution. Illinois: STIPES Publishing Co, 1990.

Wali, Mohan K., Falih Evrendilek., dan M. Siobhan Fennesy, The Environment, Science, Issues, and Solutions. Washington DC: RC Press Taylor \& France Group, 2009.

Western, Drew. Psychology Mind and Brain\& Culture. New York: Jhon Willey \& Sons, Inc,1996.

Wolkfolk, A. Educational Psychology. Seventh Edition. Boston: Allyn and Bacon A Viacom Company, 1998.

Wyss, Robert. "Field Independent/ Dependent Learning Styles and L2 Acquisition”. $\quad \underline{\text { http:// }}$ www.eltnewsletter.com/back/June 2002/art1022002.htmThe weekly column Article 102, June 2002. (diakses, 13 Juli 2011).

Yulk, Gary. Leadership in Organization. Jakarta: Prennhalindo, 1988.

68

\begin{tabular}{|l|l|l|l|}
\hline Volume XIII & Nomor 01 & Maret 2012 & ISSN 1411-1829 \\
\hline
\end{tabular}

